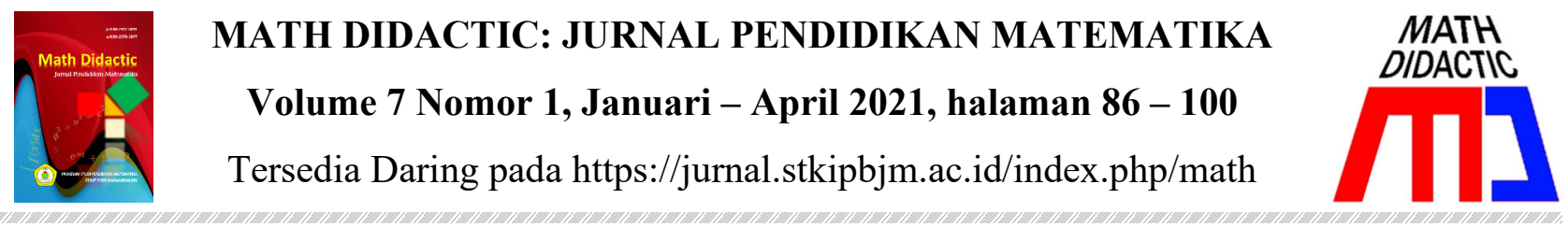

\title{
KECERDASAN LOGIS MATEMATIS DAN VISUAL SPASIAL SEBAGAI PREDIKTOR HASIL BELAJAR MATEMATIKA
}

\section{MATHEMATICAL LOGICAL INTELLIGENCES AS A PREDICTOR OF MATHEMATICS LEARNING OUTCOMES}

\author{
Fadhila Kurnia Estri, Ibrahim \\ Universitas Islam Negeri Sunan Kalijaga Yogyakarta \\ fadhilakurnia23@gmail.com,ibrahim@uin-suka.ac.id
}

\begin{abstract}
Abstrak: Penelitian ini dimaksudkan guna mengetahui prediksi hasil belajar matematika siswa mengacu dari kecerdasan logis matematis serta kecerdasan visual spasial. Penelitian ini menerapkan pendekatan kuantitatif, jenis penelitian korelasional. Penelitian dilaksanakan di SMP Negeri 16 Yogyakarta. Sampel yang digunakan sebanyak 36 siswa, metode penentuan sampel memakai cluster random sampling. Adapun instrumen yang dipakai guna menghimpun data yaitu skala kecerdasan logis matematis serta visual spasial. Teknik analisis data pada penelitian ini memakai analisis regresi ganda menggunakan software SPSS 25. Hasil penelitian menunjukkan jika kecerdasan logis matematis dan visual spasial terbukti sebagai prediktor hasil belajar matematika siswa kelas VIII SMP Negeri 16 Yogyakarta.
\end{abstract}

Kata Kunci: kecerdasan logis matematis, kecerdasan visual spasial, hasil belajar matematika

Abstract: The purpose of this research was to determine the prediction of student learning outcomes based on mathematical logical intelligence and spatial visual intelligence. This research uses a quantitative approach, a type of correlational research. That held at $16^{\text {th }}$ state junior high school Yogyakarta. The used sample is 36 students. The used sampling method is cluster random sampling. The used instrument is a scale of mathematical logical intelligence and spatial visual. The data analysis technique for regression analysis is done with SPSS 25. The results of the research prove that logical mathematical intelligence and spatial visuals are predictors of mathematics learning outcomes for Grade VIII students of SMP Negeri 16 Yogyakarta.

Keywords: mathematical logical intelligence, spatial visual intelligence, mathematics learning outcomes

Cara Sitasi: Estri, F. K., \& Ibrahim, I. (2021). Kecerdasan logis matematis dan visual spasial sebagai prediktor hasil belajar matematika. Math Didactic: Jurnal Pendidikan Matematika, 7(1), 86-100. https://doi.org/10.33654/math.v7i1.1146 
Pelajaran matematika merupakan mata pelajaran yang perlu ditingkatkan secara terus menerus untuk mencetak pola pikir manusia dalam perluasan ilmu pengetahuan dan teknologi (Agustyaningrum \& Suryantini, 2017; Dirgantoro, 2018; Kurino, 2020; Mursalin, 2016; Sholihatunnisa et al., 2018). Tujuannya supaya siswa bisa memperoleh keterampilan berpikir logis, analitis, sistematis, kritis, kreatif, dapat mengakses serta menggunakan teknologi informasi guna bertahan hidup (Avyani, Nur'aeni, \& Pranata, 2017; Kamarullah, 2017; Latif \& Akib, 2016; Ratumanan \& Laurens, 2016; Utami, Alan, \& Cahyono, 2020). Oleh sebab itu siswa lebih mudah mencerna dan memahami persoalan serta menerapkannya dalam kondisi apa pun, jika kemampuankemampuan tersebut diterapkan dan diaplikasikan pada pelajaran matematika

Pelajaran matematika merupakan pelajaran yang diajarkan di sekolah hingga perguruan tinggi serta diaplikasikan dalam kehidupan sehari-hari, sehingga pelajaran matematika memiliki peran penting guna mencerdaskan kehidupan bangsa (Achdiyat \& Utomo, 2017; Purwati \& Nurhasanah, 2016; Siagian, 2016). Namun tidak dipungkiri bahwa mayoritas siswa berasumsi jika matematika adalah pelajaran yang sukar dimengerti, membosankan, dan menakutkan (Fitroh \& Sari, 2018; Kamarullah, 2017; Purnomo, 2017; Ratumanan \& Laurens, 2016). Persoalan yang relevan dengan pelajaran matematika adalah sulitnya siswa memahami konsep matematika yang melibatkan pemahaman logika (Dwidarti, Mampouw, \& Setyadi, 2019; Harahap \& Syarifah, 2015), persoalan tersebut mengakibatkan siswa kesulitan dalam menyelesaikan soal matematika sehingga hal tersebut mengakibatkan hasil belajar siswa dalam pelajaran matematika masih rendah bahkan kurang memuaskan (Avyani, Nur'aeni, \& Pranata, 2017; Ayuwanti, 2017; Utami, Alan, \& Cahyono, 2020). Rendahnya siswa dalam pelajaran matematika mengindikasikan bahwa ketercapaian siswa dalam tujuan pelajaran matematika belum tercapai secara keseluruhan.

Aktivitas siswa yang dilakukan sehari-hari tidak terlepas dari kegiatan belajar, sehingga dapat dikatakan bahwa belajar tidak dibatasi oleh tempat dan waktu. Melalui proses belajar dapat memberikan peningkatan dan pengembangan pengetahuan pada ranah kognitif, afektif, dan psikomotorik (Lambertus, Ambarsari, \& Maonde, 2016; Sudjana, 2010; Sudaryono, 2012). Oleh sebab itu pembelajaran matematika dan hasil belajarnya yang baik dapat membawa perubahan yang positif untuk meningkatkan dan mengembangkan pola pikir manusia.

Hasil belajar matematika tidak semua tinggi atau baik (Lambertus, Ambarsari, \& Maonde, 2016; Pandin, Maonde, \& Sudia, 2019; Sukardjo \& Yusdiningtias, 2018). Hal tersebut disebabkan karena hasil belajar dipengaruhi dari sejumlah faktor diantaranya faktor eksternal serta internal (Ardila \& Hartanto, 2017; Sastro, 2018; Slameto, 2013). Kecerdasan adalah suatu faktor internal yang bisa menjadikan taraf hidup seseorang meningkat, semakin komplek dan beragam (Epriliyati, 2017; Sastro, 2018), karena kecerdasan menjadi bekal potensial dalam kehidupan seharihari (Epriliyati, 2017; Purwati \& Hasanah, 2016). Adapun implikasinya dalam pendidikan kecerdasan membantu guna 
menyelesaikan masalah dalam kehidupan sehari-hari, membantu guna menghasilkan persoalan-persoalan baru yang dihadapi untuk diselesaikan, serta menciptakan sesuatu yang akan menimbulkan penghargaan (Amstrong, 2013). Oleh sebab itu kecerdasan membekali siswa untuk mencapai keberhasilan dalam proses belajar.

Kecerdasan intelektual kira-kira menyumbang $20 \%$ dalam menentukan kesuksesan belajar, maka $80 \%$ diisi kekuatan-kekuatan lain yaitu multiple intelligences (Goleman, 2015). Multiple intelligences merupakan teori fungsi kognitif yang menerangkan bahwa setiap siswa memiliki keterampilan dan kinerja dalam sembilan jenis kecerdasan (Amstrong, 2013). Sembilan kecerdasan majemuk memiliki peran masing-masing di berbagai pelajaran untuk memenuhi kebutuhan diri dalam mengembangkan potensi akademik siswa (Fathani, 2016; Setiawan \& Ilmiyah, 2020).

Kecerdasan logis matematis mempunyai peranan penting terhadap hasil belajar matematika (Mujiani 2016; Sukardjo \& Yusdiningtias, 2018). Kecerdasan logis matematis merupakan kecerdasan yang distandarisasikan untuk mengukur ketercapaian kemampuan siswa dalam pembelajaran matematika (Ardiansyah, 2020; Dara \& Budiarto, 2018; Musrikah, 2016; Putri, 2018). Siswa yang memiliki kecerdasan logis dapat melakukan perhitungan dengan matematis, berpikir logis, serta memiliki ketajaman dalam menganalisis pola-pola dan keterikatan-keterikatan (Amstrong 2013; Jasmine, 2012; Milsan \& Wewe, 2019; Niyati \& Kurniah, 2016; Said \& Budimanjaya, 2015). Oleh sebab itu menggunakan kecerdasan logis matematis siswa dapat tambah gampang memecahkan persoalan-persoalan matematika yang mendasari berbagai konsep logika.

Kecerdasan visual spasial juga memiliki kontribusi dalam membantu siswa untuk belajar matematika (Achdiyat \& Utomo, 2017; Buana, 2018; Mananeke, Wenas, \& Sambuaga, 2017). Sebab, siswa yang mempunyai kecerdasan visual spasial bisa memahami, membayangkan, dan memvisualisasi gambar dan ruang secara akurat (Achdiyat \& Utomo, 2017; Amstrong, 2013; Jasmine, 2012; Said \& Budimanjaya, 2015). Oleh sebab itu dengan kecerdasan visual spasial siswa akan tambah gampang dalam memecahkan persoalan-persoalan matematika yang mendasari berbagai konsep abstrak.

Aktivitas siswa ketika mempraktikkan cara menghitung, mengukur serta mengerjakan sesuatu yang sifatnya matematis maka siswa akan membutuhkan kecerdasan visual spasial (Alimuddin \& Trisnowali, 2020; Nugraha, 2018). Mempelajari geometri dapat mendesak siswa untuk berimajinasi menetapkan letak serta ukuran sebuah objek serta memvisualisasikan objek untuk menggambarkan ide-idenya (Mananeke, Wenas, \& Sambuaga, 2017; Syafiqah, Ruslan, \& Darwis, 2020; Zahra, Widyawati, \& Ningsih, 2017).

Sebagian guru sering kali tidak memahami kecerdasan dengan menyeluruh pada belajar mengajar di kelas. Maka dari itu penelitian mengenai kecerdasan logis matematis dan visual spasial penting untuk dilakukan terutama bagi guru, dengan tujuan untuk mengetahui prediksi hasil belajar matematika siswa mengacu dari kecerdasan logis matematis serta visual spasial. Berdasarkan alasan itu penulis tertarik guna mengkaji dan terdorong 
mengadakan penelitian berjudul "Kecerdasan Logis Matematis dan Visual Spasial sebagai Prediktor Hasil Belajar Matematika"

\section{Metode Penelitian}

Penelitian ini berjenis korelasional dengan menerapkan pendekatan kuantitatif. Data yang diperoleh dalam penelitian ini tidak hanya sekedar hubungan namun adanya pengaruh antara dua variabel atau lebih dalam situasi realistik yang tidak dapat dieksperimenkan dan analisis data yang diperoleh bersifat statistik dengan tujuan menguji hipotesis yang diterapkan.

Seluruh kelas VIII A, B, serta C SMP Negeri 16 Yogyakarta menjadi

populasi pada penelitian ini. Sampel

Tabel 2. Kisi-kisi Kecerdasan Logis Matematis dan Visual Spasial

\begin{tabular}{cl}
\hline \multicolumn{1}{c}{ Komponen } & \multicolumn{1}{c}{ Kisi-kisi } \\
\hline $\begin{array}{c}\text { Perhitungan secara } \\
\text { matematis }\end{array}$ & Kemampuan siswa dalam berhitung \\
\cline { 2 - 3 } Berpikir Logis & Kemampuan siswa mengurutkan dan mengklasifikasi sesuatu \\
\hline Pemecahan Masalah & $\begin{array}{l}\text { Kemampuan siswa dalam memecahkan persoalan-persoalan } \\
\text { matematika }\end{array}$ \\
\hline $\begin{array}{c}\text { Pertimbangan induktif dan } \\
\text { pertimbangan deduktif }\end{array}$ & $\begin{array}{l}\text { Kemampuan berpikir siswa untuk menarik suatu kesimpulan } \\
\text { apabila dihadapkan pada suatu pernyataan }\end{array}$ \\
\hline $\begin{array}{c}\text { Ketajaman pola-pola serta } \\
\text { hubungan-hubungan }\end{array}$ & Siswa dapat menganalisis pola-pola yang saling berhubungan \\
\hline $\begin{array}{c}\text { Membayangkan gambar dan } \\
\text { ruang secara akurat }\end{array}$ & $\begin{array}{l}\text { Mecerdasan Visual Spasial } \\
\text { sehingga menimbulkan imajinasi }\end{array}$ \\
\hline $\begin{array}{c}\text { Belajar mengamati dan } \\
\text { menaruh perhatian secara } \\
\text { detail }\end{array}$ & $\begin{array}{l}\text { Memberi perhatian pada benda dan } \\
\text { memperhatikan cara kerjanya }\end{array}$ \\
\hline $\begin{array}{c}\text { Mempresentasikan ide secara } \\
\text { visual spasial }\end{array}$ & Memvisualisasi, mewakili ide-ide visual spasial secara grafis \\
\hline Sketsa dan gambar & Mensketsa gambar dengan baik \\
\hline
\end{tabular}

diambil 12 siswa dari masing-masing kelas VIII A, B, serta C, dengan menerapkan teknik cluster random sampling. Masingmasing sampel diambil 4 siswa secara acak dengan kategori kemampuan tinggi, sedang, dan rendah, menggunakan rumusan kategori yang dapat ditampilkan dalam Tabel 1.

Tabel 1. Rumusan Kategori Sampel

\begin{tabular}{lc}
\multicolumn{1}{c}{ Kriteria } & Kategori \\
\hline $\mathrm{X}>($ Mean $+1 \mathrm{SD})$ & Tinggi \\
\hline$($ Mean-1 SD) $<\mathrm{X} \leq($ Mean + I SD $)$ & Sedang \\
\hline $\mathrm{X}<($ Mean- 1 SD $)$ & Rendah \\
\hline
\end{tabular}

Instrumen dalam penelitian ini berupa skala kecerdasan logis matematis serta visual spasial serta lembar validasi skala kecerdasan logis matematis serta visual spasial. Adapun kisi-kisi instrumen ditampilkan dalam Tabel 2. 
Instrumen penelitian divalidasi dan diuji reliabilitasnya. Validitas isi instrumen dilakukan oleh tiga validator. Validitas isi diperoleh dengan cara meminta komentar serta masukan para ahli yang berkompeten dibidangnya, karena pernyataan pada skala mengacu pada pelajaran matematika berlandaskan aspek kecerdasan, maka kriteria dosen yang dipilih yaitu dua dosen pendidikan matematika serta dosen psikologi. Hasil data yang diolah menggunakan rumus CVR menunjukkan bahwa 30 butir pernyataan skala kecerdasan logis matematis serta visual spasial diperoleh rerata CVR 1. Hal tersebut menunjukkan bahwa seluruh butir pernyataan skala kecerdasan logis matematis serta visual spasial dinyatakan valid.

Uji reliabilitas instrumen diujicobakan pada dua kelas yang tidak masuk dalam sampel penelitian serta diambil sebanyak 32 responden dengan menerapkan teknik random sampling. Uji reliabilitas diolah menggunakan rumus Cronbach's Alpha. Nilai koefisien reliabilitas instrumen skala kecerdasan logis matematis diperoleh sebesar 0,729 > 0,349 , sedangkan skala kecerdasan visual spasial diperoleh sebesar $0,821>0,349$. Sedemikian itu bisa diringkas jika skala kecerdasan logis matematis serta visual spasial dinyatakan reliabel atau terpercaya selaku alat penghimpun data pada penelitian.

Teknik pengumpulan data dalam penelitian ini menggunakan skala kecerdasan logis matematis serta visual spasial dan hasil belajar matematika pada Penilaian Tengah Semester II (PTS II). Selanjutnya akan dianalisis untuk memperoleh data yang akurat dan ditarik kesimpulan sesuai dengan kebutuhan penelitian. Sasaran yang diharapkan dalam penelitian ini dapat memberikan pengaruh positif serta signifikan kecerdasan logis matematis serta visual spasial kepada hasil belajar matematika, sehingga penelitian ini dapat memberikan sumbangan berupa kajian konseptual tentang beberapa faktor yang mempengaruhi hasil belajar siswa antara lain kecerdasan logis matematis dan visual spasial serta dapat berguna bagi khalayak umum, terutama guru matematika.

Teknik analisis data diolah dan dianalisis menggunakan statistik. Analisis data dilaksanakan guna mendeskripsikan data yang diperoleh pada penelitian. Analisis selanjutnya yaitu pengujian prasyarat analisis berganda yang mencakup uji asumsi klasik serta uji hipotesis menggunakan taraf signifikan $\alpha=0,05 \%$. Uji asumsi klasik yang digunakan peneliti tersusun atas uji normalitas, multikolinearitas serta uji heteroscedasticity. Kemudian uji hipotesis terdiri dari uji parsial (uji t), uji pengaruh simultan (uji F), koefisien determinasi, dan interpretasi model.

\section{Hasil Penelitian dan Pembahasan}

\section{Hasil}

Berlandaskan hasil analisis deskriptif didapat terkait perbedaan rerata skor kecerdasan logis matematis serta visual spasial didapat selisihnya sebesar 6,28. Selanjutnya terkait standar deviasi skor kecerdasan logis matematis lebih rendah dari skor kecerdasan visual spasial. Hal ini menunjukkan bahwa sebagian besar angka mendekati rata-rata, artinya sebaran skor kecerdasan logis matematis dalam sampel yang telah dipilih relatif homogen dan 
mengumpul di sekitar rata-ratanya. Standar deviasi kecerdasan visual spasial lebih tinggi dari standar deviasi kecerdasan logis matematis, berarti bahwa sebagian besar angka menjauhi rata-ratanya, artinya sebaran skor kecerdasan visual spasial dalam sampel yang dipilih lebih luas dan tidak mengumpul pada rata-ratanya. Rincian hasil perhitungan data statistik deskriptif ditampilkan dalam Tabel 3.

Tabel 3. Data Statistik Deskriptif Variabel Penelitian

\begin{tabular}{cccc}
\hline $\begin{array}{c}\text { Parameter } \\
\text { Statistik } \\
\text { Deskriptif }\end{array}$ & $\begin{array}{c}\text { Kecerdasan Logis } \\
\text { Matematis }\end{array}$ & $\begin{array}{c}\text { Kecerdasan } \\
\text { Visual Spasial }\end{array}$ & $\begin{array}{c}\text { Hasil } \\
\text { Belajar }\end{array}$ \\
\hline Minimum & 87,061 & 77,459 & 50 \\
\hline Maksimum & 140,115 & 133,850 & 100 \\
\hline Rata-rata & 108,362 & 102,079 & 76,39 \\
\hline Standar Deviasi & 12,173 & 14,821 & 13,21 \\
\hline
\end{tabular}

Uji normalitas pada penelitian ini memakai metode Kolmogorov-Smirnov. Berlandaskan uji normalitas membuktikan jika nilai sig $<0,05$. Sedemikian itu terdapat hubungan di antara kecerdasan logis matematis serta kecerdasan visual spasial kepada hasil belajar matematika. Ringkasan hasil perhitungan uji normalitas residual ditampilkan dalam Tabel 4.

Tabel 4. Hasil Uji Normalitas Residual

\begin{tabular}{cc}
\hline Sig & Keterangan \\
\hline 0,196 & Normal \\
\hline
\end{tabular}

Uji multikolinearitas pada penelitian ini memakai nilai toleran serta nilai VIF. Berlandaskan uji multikolinearitas menunjukkan bahwa nilai toleran kecerdasan logis matematis serta visual spasial $<0,100$ dan nilai VIF kecerdasan logis matematis serta visual spasial $>10,00$, memberikan kesimpulan bahwa data terbebas dari multikolinearitas. Ringkasan hasil perhitungan uji multikolinearitas ditampilkan dalam Tabel 5.

Tabel 5. Hasil Uji Multikolinearitas

\begin{tabular}{ccc}
\hline Model & \multicolumn{2}{c}{ Collinearity Statistics } \\
& Tolerance & VIF \\
\hline Kecerdasan Logis Matematis & 0,990 & 1,010 \\
\hline Kecerdasan Visual Spasial & 0,990 & 1,010 \\
\hline
\end{tabular}

Uji heteroskedastisitas pada memberikan kesimpulan bahwa data penelitian ini memakai metode uji Glejser. terbebas dari heteroskedastisitas. Ringkasan Berlandaskan uji heteroskedastisitas hasil perhitungan uji heteroskedastisitas membuktikan jika nilai sig kecerdasan logis ditampilkan dalam Tabel 6. matematis serta visual spasial $>0,05$,

Tabel 6. Hasil Uji Heteroskedastisitas

\begin{tabular}{cc}
\hline Model & Sig \\
\hline Kecerdasan Logis Matematis & 0,706 \\
\hline Kecerdasan Visual Spasial & 0,764 \\
\hline
\end{tabular}


Data-data di atas telah terpenuhi dan terbebas dari penyimpangan syarat-syarat asumsi klasik. Selanjutnya dilakukan pengujian hipotesis, yaitu uji parsial (uji t) menggunakan nilai sig dan membandingkan nilai $t_{\text {hitung }}$ dengan nilai $t_{\text {tabel }}$. Nilai $t_{\text {tabel }}$ diperoleh dengan menggunakan presentase titik distribusi, karena dalam analisis regresi menggunakan probabilitas dua sisi maka dibutuhan nilai derajat bebas atau degree of freedom (df). Didapatkan nilai df $=33$, dengan melihat titik persentase distribusi $\mathrm{T}$ maka diperoleh nilai $t_{\text {tabel }}$ sebesar 2,035.
Diperoleh nilai $t_{\text {hitung }}$ kecerdasan logis matematis serta kecerdasan visual spasial $>$ 2,035 .

Hasil uji t membuktikan bahwa nilai $\operatorname{sig}<0,05$ dan $t_{\text {hitung }}>t_{\text {tabel }}$, memberikan kesimpulan bahwa kecerdasan logis matematis berpengaruh positif serta signifikan kepada hasil belajar matematika dan kecerdasan visual spasial berpengaruh positif juga signifikan kepada hasil belajar matematika. Ringkasan hasil uji $t$ ditampilkan dalam Tabel 7.

Tabel 7. Hasil Uji t

\begin{tabular}{ccccc}
\hline & Model & B & T & Sig \\
\hline \multirow{3}{*}{1} & $($ Constant $)$ & $-15,484$ & $-0,823$ & 0.146 \\
\cline { 2 - 5 } & Kecerdasan Logis Matematis & 0,484 & 3.363 & 0.002 \\
\cline { 2 - 5 } & Kecerdasan Visual Spasial & 0,386 & 3.271 & 0.003 \\
\hline
\end{tabular}

Uji pengaruh simultan (uji F) menggunakan nilai sig dan perbandingan nilai $F_{\text {hitung }}$ dengan nilai $F_{\text {tabel }}$. Nilai $F_{\text {tabel }}$ diperoleh dengan menggunakan presentase titik distribusi, karena dalam analisis regresi menggunakan probabilitas dua sisi maka dibutuhkan nilai derajat bebas atau degree of freedom $(\mathrm{df}(\mathrm{n} 1))$ dan $(\mathrm{df}(\mathrm{n} 2))$. Didapatkan nilai $\operatorname{df}(\mathrm{n} 1)=2 \operatorname{dan} \operatorname{df}(\mathrm{n} 2)=33$, dengan melihat titik persentase distribusi $\mathrm{F}$ maka diperoleh nilai $F_{\text {tabel }}$ sebesar 3,28.
Hasil uji $\mathrm{F}$ membuktikan jika nilai sig $<0,05$ dan $F_{\text {hitung }}>F_{\text {tabel }}$, memberikan kesimpulan jika ada pengaruh positif serta signifikan secara bersama-sama antara kecerdasan logis matematis serta kecerdasan visual spasial kepada hasil belajar matematika. Ringkasan hasil uji $\mathrm{F}$ ditampilkan dalam Tabel 8.

Tabel 8. Hasil Uji F

\begin{tabular}{ccc} 
Model & F & Sig \\
\hline Regresi & 12.230 & 0.000 \\
\hline
\end{tabular}

Koefisien determinasi diperoleh dari hasil perkalian nilai Adjusted $R$ Square dengan 100\%. Nilai Adjusted $R$ Square menunjukkan bahwa proporsi pengaruh kecerdasan logis matematis serta kecerdasan visual spasial terhadap variabel hasil belajar matematika siswa sejumlah
39,1\%. Sisanya 60,9\% dipengaruhi oleh variabel lain yang tidak diteliti oleh peneliti. Ringkasan hasil uji koefisien determinasi ditampilkan dalam Tabel 9. 
Tabel 9. Koefisien Determinasi

\begin{tabular}{ccccc} 
Model & $\mathbf{R}$ & $\mathbf{R}$ Square & $\begin{array}{c}\text { Adjusted } \boldsymbol{R} \\
\text { Square }\end{array}$ & $\begin{array}{c}\text { Std. Error of the } \\
\text { Estimate }\end{array}$ \\
\hline 1 & 0,652 & 0,426 & 0,391 & 10.3082 \\
\hline
\end{tabular}

\section{Pembahasan}

Hasil uji hipotesis pertama dalam penelitian ini menandakan jika ada pengaruh positif serta signifikan kecerdasan logis matematis kepada hasil belajar matematika siswa kelas VIII SMPN 16 Yogyakarta. Hal ini ditunjukkan pada nilai koefisien regresi $\left(X_{1}\right)$ bernilai positif, dapat diartikan bahwa siswa yang memperoleh hasil belajar matematika yang tinggi disebabkan karena siswa memiliki kecerdasan logis matematis yang tinggi. Sebaliknya, siswa yang mendapat hasil belajar matematika yang rendah disebabkan siswa mempunyai kecerdasan logis matematis yang rendah. Nilai koefisien regresi $\left(X_{1}\right)$ diperoleh sebesar 0,484, bertambahnya nilai setiap satuan dapat meningkatkan hasil belajar matematika sebesar 0,484 dengan syarat variabel lain dianggap tetap.

Selanjutnya perolehan nilai sig pada uji $t$ bernilai positif dan $<0,05$ serta nilai $t_{\text {hitung }}>t_{\text {tabel. }}$ Artinya nilai rata-rata kecerdasan logis matematis lebih besar dari perolehan nilai hasil belajar, sehingga selisih rata-rata menghasilkan nilai positif dan perbandingan rata-rata variabel bebas dan rata-rata variabel terikat tidak terdistribusi rata. Sedemikian itu, bertambah tinggi kecerdasan logis matematis siswa pastinya bertambah tinggi juga hasil belajar matematika siswa.

Alasan kecerdasan logis matematis dapat berpengaruh positif kepada hasil belajar matematika karena kecerdasan logis matematis memiliki hubungan dengan komponen-komponen yang ada pada pelajaran matematika serta kecerdasan logis matematis berkaitan dengan aktivitas siswa pada pembelajaran (Asmal, 2020; Nisa, Mukhlis, \& Maswar, 2020; Wulandari \& Fatmahanik, 2020). Hal tersebut memungkinkan bahwa dalam pembelajaran matematika guru membiasakan siswa untuk belajar menemukan konsep terlebih dahulu agar siswa dapat menerapkan kemampuan bernalarnya, karena di dalam soal-soal matematika tidak hanya mengajarkan keterampilan berhitung, mengerjakan soal, dan bukan hanya aspek praktis yang harus dikejar. Siswa dituntut agar dapat bernalar dan menganalisis penyelesaiannya dengan cermat dan dapat menganalisis kekonsistenan angka-angka yang saling berkaitan dan deret urutan paling logis (Asmal, 2020; Nisa, Mukhlis, \& Maswar, 2020; Wulandari \& Fatmahanik, 2020).

Hasil uji hipotesis kedua dalam penelitian ini menandakan jika ada pengaruh positif serta signifikan kecerdasan visual spasial kepada hasil belajar matematika siswa kelas VIII SMPN 16 Yogyakarta. Hal ini ditunjukkan pada nilai koefisien regresi $\left(X_{2}\right)$ bernilai positif, dapat diartikan bahwa siswa yang memperoleh hasil belajar matematika yang tinggi disebabkan karena siswa memiliki kecerdasan visual spasial yang tinggi. Sebaliknya, siswa yang mendapat hasil belajar matematika yang rendah disebabkan karena siswa mempunyai kecerdasan visual spasial yang tidak tinggi. Nilai koefisien regresi $\left(X_{2}\right)$ diperoleh sebesar 0,386, bertambahnya nilai setiap satuan dapat meningkatkan hasil belajar matematika 
yaitu 0,386 dengan syarat variabel lain dinilai tetap.

Selanjutnya, perolehan nilai sig pada uji t bernilai positif dan $<0,05$ serta nilai $t_{\text {hitung }}>t_{\text {tabel }}$. Artinya nilai rata-rata kecerdasan visual spasial lebih besar dari perolehan nilai hasil belajar, sehingga selisih rata-rata menghasilkan nilai positif dan perbandingan rata-rata variabel bebas dan rata-rata variabel terikat tidak terdistribusi rata. Sedemikian itu, bertambah tinggi kecerdasan visual spasial siswa pastinya bertambah tinggi juga hasil belajar matematika siswa.

Alasan kecerdasan visual spasial dapat berpengaruh positif kepada hasil belajar matematika karena kecerdasan visual spasial memiliki hubungan dengan komponen-komponen yang ada pada pelajaran matematika dan kecerdasan visual spasial adalah keterampilan yang berhubungan terhadap aktivitas siswa pada pembelajaran matematika (Ahmad \& Etmy, 2019; Ani, Maulana, \& Sunaengsih, 2017). Hal tersebut memungkinkan bahwa saat pembelajaran matematika guru sering menerapkan pembelajaran menggunakan media pembelajaran salah satunya yaitu alat peraga. Alat peraga menjadi jalan keluar untuk menangani kesukaran siswa untuk menyelesaikan persoalan matematika terutama dalam materi geometri (Amalia, Jaeng, \& Rochaminah, 2020; Marfu'ah, Julaeha, \& Solihah, 2019).

Alat peraga adalah suatu media pembelajaran yang diinterpretasikan secara visual (Karo \& Rohani, 2018; Nurrita, 2018; Sugiyati, 2016). Penggunaan alat peraga dapat mengakomodasi siswa dalam memahami konsep yang bersifat abstrak dan memberikan rangsangan atau stimulus terutama pada aspek kognitif dan afektif siswa (Kania, 2016; Marfu'ah, Julaeha, \&
Solihah, 2019; Situmorang \& Sopia, 2020), sehingga dapat menumbuhkan dan membangkitkan minat siswa untuk belajar hal baru dan memberikan pengaruh positif terhadap psikologis siswa. Sedemikian itu siswa dapat belajar membayangkan, mengamati dan menaruh perhatian pada materi yang disajikan apa saja yang diketahui dan dapat mengembangkan kemampuan siswa mengingat suatu gambar dalam pikirannya kemudian menuliskannya.

Hal tersebut juga memungkinkan bahwa dalam pembelajaran matematika guru tidak hanya sekedar menyampaikan materi dengan menggunakan media pembelajaran, namun guru memberikan latihan-latihan soal yang dapat menuntut kemampuan berpikir kreatif dan membiasakan siswa untuk berusaha menyelesaikannya. Sedemikian itu kecerdasan visual spasial siswa semakin terasah dan berkembang.

Hasil uji hipotesis ketiga menandakan jika terdapat pengaruh positif serta signifikan kecerdasan logis matematis serta visual spasial secara bersama-sama kepada hasil belajar matematika siswa kelas VIII SMPN 16 Yogyakarta. Hal tersebut dibuktikan dari nilai sig dalam uji $\mathrm{F}<0,05$ serta nilai $F_{\text {hitung }}>F_{\text {tabel }}$ dan bisa diketahui atas nilai Adjusted $R$ Square bahwa proporsi pengaruh variabel bebas keduanya dengan bersama-sama kepada hasil belajar sebesar $39,1 \%$. Sisanya ada faktor lain baik faktor internal ataupun eksternal yang tidak terdapat dalam penelitian ini sebesar $60,9 \%$. Tidak dipungkiri bahwa kedua faktor tersebut dapat memastikan kesuksesan atau kegagalan yang dialami siswa.

Kecerdasan logis matematis serta visual spasial dengan berbarengan berperan 
untuk menentukan capaian belajar matematika siswa, karena kedua komponen kecerdasan tersebut jika diaplikasikan pada pembelajaran matematika akan mempengaruhi hasil belajar matematika siswa (Hitalessy, Mataheru, \& Ayal, 2020). Sebagai tolok ukur kecerdasan logis matematis yang memfokuskan terhadap kapasitas otak untuk mengolah angka, berpikir logis, keterampilan dalam menganalisis pola yang saling berhubungan dan kemampuan berhitung (Amstrong, 2013; Jasmine, 2012; Milsan \& Wewe, 2019; Niyati \& Kurniah, 2016; Said \& Budimanjaya, 2015). Apabila dipadankan dengan adanya kecerdasan visual spasial, maka tidaklah mengherankan jika perpaduan antara kedua kecerdasan tersebut memberikan pengaruh yang positif untuk mencapai kesuksesan belajar.

Ketika siswa mempraktikkan cara menghitung, mengukur serta mengerjakan sesuatu yang sifatnya matematis dalam materi teorema pythagoras, lingkaran, garis singgung lingkaran, dan bangun ruang, dimana keempat materi tersebut merupakan bagian dari geometri yang lebih menekankan pada gambar, maka dalam menyelesaikan persoalan tersebut peran kecerdasan visual spasial sangat dibutuhkan. Siswa dengan kecerdasan visual spasial dalam memecahkan persoalan pada materi lingkaran akan memiliki kepekaan menganalisis unsur-unsur lingkaran, sudut pusat serta sudut keliling lingkaran, pada materi teorema pythagoras siswa memiliki kepekaan dalam menganalisis sudut dan diagonal, sedangkan dalam materi bangun ruang sisi datar akan memiliki kepekaan dalam menganalisis sisi, rusuk, titik sudut, diagonal bidang, diagonal ruang, garis, sudut, serta ruang. Sedemikian itu siswa dapat belajar mengamati dan menaruh perhatian dari penyajian gambar yang disediakan secara detail apa saja yang diketahui, sehingga siswa dapat menafsirkan hal yang tersirat pada objek yang diketahui dan memvisualisasikan ideidenya melalui gambar, karena dengan menggunakan gambar dapat memperjelas dan memperkonkret hal-hal yang abstrak serta dapat menuntut siswa menggunakan kemampuan imajinasinya dalam gambar dan ruang.

Adanya peran kecerdasan logis matematis untuk mengerjakan soal-soal yang berhubungan terhadap bahan tersebut siswa dapat memikirkan serta menyusun solusi yang logis, memecahkan masalah matematika tidak hanya mengandalkan perhitungan saja namun dapat menerapkan berpikir dalam pola sebab akibat, dan siswa dapat mempertimbangkan penyelesaiannya. Sedemikian itu kecerdasan logis matematis serta visual spasial dengan bersama-sama akan semakin terasah serta berkembang. Hal-hal tersebut apabila diterapkan pada diri siswa, maka dalam menyelesaikan soalsoal terutama pada Penilaian Tengah Semester II (PTS II) tidak akan mengalami kesulitan, dengan begitu kedua komponen tersebut terlibat dengan aktivitas siswa dalam pelajaran matematika.

\section{Simpulan dan Saran}

\section{Simpulan}

Berlandaskan hasil analisis peneliti menunjukkan jika kecerdasan logis matematis dan visual spasial terbukti sebagai prediktor hasil belajar matematika siswa kelas VIII SMP Negeri 16 Yogyakarta.

Saran 
Guru lebih memperhatikan aspekaspek pada kecerdasan logis matematis serta visual spasial dengan mendesain perangkat pembelajaran yang dapat mengakomodasi aspek tersebut. Bagi siswa diharapkan dapat berlatih soal-soal yang melibatkan kemampuan tingkat tinggi agar kecerdasan mereka semakin terasah dan berkembang.

\section{Daftar Pustaka}

Achdiyat, M., \& Utomo, R. (2017). Kecerdasan visual-spasial, kemampuan numerik, dan prestasi belajar matematika. Formatif: Jurnal Ilmiah Pendidikan MIPA, 7 (3), 234245.

http://dx.doi.org/10.30998/formatif.v $7 \mathrm{i} 3.2234$

Agustyaningrum., N., \& Suryantini, S. (2017). Hubungan kebiasaan belajar dan kepercayaan diri dengan hasil belajar matematika siswa kelas viii smp n 27 batam. JIPMat, 1 (2), 158164.

https://10.26877/jipmat.v1i2.1242

Ahmad., \& Etmy, D. (2019). Hubungan kemampuan spasial dengan prestasi belajar matematika siswa pada materi bangun ruang sisi datar kelas viii madrasah tsanawiyah. El-Hikmah: Jurnal Pendidikan dan Kajian Keislaman, 2 (1), 75-98.

Alimuddin., H., \& Trisnowali, A. (2018). Profil kemampuan spasial dalam menyelesaikan masalah geometri siswa yang memiliki kecerdasan logis matematis tinggi ditinjau dari perbedaan gender. ALFAmath: Jurnal Pendidikan Matematika, 1 (1), 23-35. https://doi.org/10.47165/alfamath.v1i 1.43
Amalia, R., Jaeng, M., \& Rochaminah, S. (2020). Penerapan pendekatan somatos auditori visual; intelektual (savi) berbantuan alat peraga pada materi luas permukaan dan volume limas. Jurnal Elektronik Pendidikan Matematika Tadulako, 7 (3), 265-276.

Amstrong, T. (2013). Kecerdasan multipel di dalam kelas. Jakarta: Permata Puri Media.

Ani, A., Maulana, M., \& Sunaengsih, C. (2017). Pengaruh pendekatan kontekstual berbasis kecerdasan visual-spasial terhadap kemampuan pemahaman matematis siswa sekolah dasar. Jurnal Pena Ilmiah, 2 (1), 971980. https://10.17509/jpi.v2i1.11234

Ardiansyah, M. (2020). Kontribusi tingkat pendidikan orang tua, lingkungan, dan kecerdasan logis terhadap kemampuan berpikir kritis matematis. Jurnal Pendidikan Matematika (Kudus), 3 (2), 185-200. http://dx.doi.org/10.21043/jmtk.v3i2. 8578

Ardila, A., \& Hartanto, S. (2017). Faktor yang mempengaruhi rendahnya hasil belajar matematika siswa $\mathrm{mts}$ iskandar muda batam. Pythagoras: Jurnal Program Studi Pendidikan Matematika, 6 (2), 175-186. https://10.33373/pythagoras.v6i2.966

Asmal, M. (2020). Pengaruh kecerdasan logis matematis terhadap kemampuan pemecahan masalah siswa kelas vii smpn 30 makassar. Elips: Jurnal Pendidikan Matematika, 1 (1), 30-36. https://doi.org/10.47650/elips.v1i1.12 2

Avyani, T., Nur'aeni, E., \& Pranata O. (2017). Penggunaan teori van hiele untuk meningkatkan hasil belajar siswa pada materi jaring-jaring kubus 
dan balok. Pedadidaktika: Jurnal Ilmiah Pendidikan Guru Sekolah Dasar, 4 (2), 19-27.

Ayuwanti, I. (2017). Meningkatkan aktivitas dan hasil belajar matematika menggunakan model pembelajaran kooperatif tipe group investigation di smk tuma'ninah yasin metro. SAP (Susunan Artikel Pendidikan), 1 (2), 105-114.

http://dx.doi.org/10.30998/sap.v1i2.1 017

Buana, R. S. (2018). Pengaruh kecerdasan spasial visual dan motivasi belajar terhadap prestasi belajar matematika (survei pada siswa sman di kota tangerang selatan. Alfarisi: Jurnal Pendidikan MIPA, 1 (2), 196-203.

Dara, R. \& Budiarto, M. T. (2018). Kemampuan pemecahan masalah aljabar siswa smp menggunakan tahapan polya berdasarkan kecerdasan logis-matematis. Jurnal Ilmiah Pendidikan Matematika (MATHEdunesa), 7 (2), 176-180.

Dirgantoro, K. P (2018). Kompetensi guru matematika dalam mengembangkan kompetensi matematis siswa. Scholaria: Jurnal Pendidikan dan Kebudayaan, 8 (2), 157-166. https://doi.org/10.24246/j.js.2018.v8. i2.p157-166

Dwidarti, U., Mampouw, H. L., \& Setyadi, D. (2019). Analisis kesulitan siswa dalam menyelesaikan soal cerita pada materi himpunan. Jurnal Cendekia: Jurnal Pendidikan Matematika, 3 (2), 315-322.

https://doi.org/10.31004/cendekia.v3i 2.110

Epriliyati, L. W (2017). Pengaruh kecerdasan logis matematis dan spasial-visual terhadap hasil belajar matematika siswa smp. Mathedunesa: Jurnal Ilmiah Pendidikan Matematika, 9 (2), 2-15

Fathani, A. H. (2016). Pengembangan literasi matematika sekolah dalam perspektif multipel intelligences. Jurnal EduSains, 4 (2), 136-150. https://doi.org/10.23971/eds.v4i2.524

Fitroh, M. I., \& Sari, A. F. (2018). Pengaruh persepsi matematika siswa terhadap hasil belajar siswa di smkn 1 surabaya tahun ajaran 2017/2018. Jurnal Elektronik Pembelajaran Matematika, 5 (2), 147-156.

Goleman, D. (2015). Emotional intelegence, kecerdasan emosional "mengapa el lebih penting dari iq". Jakarta: Gramedia Pustaka Utama.

Harahap, D. H., \& Syarifah, R. (2015). Studi kasus kesulitan belajar matematika. Jurnal Psikologi, 11 (1), 20-30.

Hitalessy, M., Mataheru, W., \& Ayal, C. (2020). Representasi matematis siswa dalam pemecahan masalah perbandingan trigonometri pada segitiga siku-siku ditinjau dari kecerdasan logis matematis, linguistik dan visual spasial. Jurnal Pendidikan Matematika (Jumadika), 2 (1), 1-15. https://doi.org/10.30598/jumadikavol 2iss1year2020page1-15

Jasmine, J. (2012). Metode mengajar multiple intellegences. Bandung: Nuansa Cendekia.

Kamarullah. (2017). Pendidikan matematika di sekolah kita. Al Khawarizmi: Jurnal Pendidikan dan Pembelajaran Matematika, 1 (1), 21 32.

http://dx.doi.org/10.22373/jppm.v1i1 .1729 
Kania, N. (2016). Evektivitas penggunaan alat peraga maya (virtual manipulative) terhadap peningkatan visual thinking siswa. Theorems (The Original Research of Mathematics, 1 (1), 45-57. http://dx.doi.org/10.31949/th.v1i1.29 1

Karo, I., \& Rohani. (2018). Manfaat media dalam pembelajaran. Jurnal Axiom, 7 (1), 91-96. doi: http://dx.doi.org/10.30821/axiom.v7i 1.1778 .

Kurino, Y. D. 2020). Model problem based learning (pbl) pada pelajaran matematika di sekolah dasar. Jurnal Elementari Edukasia, 3 (1), 150-154. http://dx.doi.org/10.31949/jee.v3i1.2 240

Lambertus., Ambarsari, M., \& Maonde, F. (2016). Pengaruh sikap siswa terhadap hasil belajar matematika melalui kombinasi model pembelajaran kooperatif. Jurnal Pendidikan Matematika, 7 (2), 105124.

http://dx.doi.org/10.36709/jpm.v7i2 . 3086

Latif, S., \& Akib I. (2016). Mathematical connection ability in solving mathematics problem based on initial abilities of students at smpn 10 bulukumba. Jurnal Daya Matematis, $4 \quad$ (2), 207-217. https://doi.org/10.26858/jds.v4i2.289 9

Mananeke, S. G., Wenas, J.R., \& Sambuaga, O. T. (2017). Hubungan kecerdasan visual-spasial dengan hasil belajar matematika siswa pada materi geometri. Jurnal Sains, Matematika, \& Edukasi (JSME) FMIPA Unima, 5 (1), 87-91.
Marfu'ah, I., Julaeha, S., \& Solihah, A. (2019). Pengaruh penggunaan alat peraga pada materi pokok dimensi tiga terhadap hasil belajar matematika. SAP (Susunan Artikel Pendidikan), 4 (2), 137-142. http://dx.doi.org/10.30998/sap.v4i2.4 261

Milsan, A. L., \& Wewe, M. (2019). Hubungan antara kecerdasan logis matematis dengan hasil belajar matematika. Journal of Education Technology, 2 (2), 65-69. http://dx.doi.org/10.23887/jet.v2i2.16 183

Mujiani, D. S. (2016). Pengaruh media pembelajaran dan kecerdasan logis matematis terhadap hasil belajar matematika siswa. Jurnal Pendidikan Dasar, 7 (2), 199-209.

Mursalin. (2016). Pembelajaran geometri bidang datar di sekolah dasar berorientasi teori balajar piaget. Jurnal Dikma, 4 (2), 250-258.

Musrikah. (2016). Model pembelajaran matematika realistik sebagai optimalisasi kecerdasan logika matematika pada siswa $\mathrm{sd} / \mathrm{mi}$. Ta'allum: Jurnal Pendidikan Islam, 4 (1), 1-18. https://doi.org/10.21274/taalum.2016 .4.1.1-18

Nisa, F. B., Mukhlis, M., \& Maswar. (2020). Analisis hubungan antara kecerdasan logis matematis dengan kemampuan komunikasi matematis siswa. Alifmatika: Jurnal Pendidikan dan Pembelajaran Matematika, 2 (2), 199-211.

https://doi.org/10.35316/alifmatika.2 020.v2i2.199-211

Niyati, M., \& Kurniah, N. (2016). 
Meningkatkan kecerdasan logika matematika melalui permainan congklak tradisional. Jurnal Ilmiah $\begin{array}{lll}\text { Potensia, } & 1 & \text { (2), }\end{array}$ https://doi.org/10.33369/jip.1.2.78-83

Nugraha, Y. (2018). Kontribusi kecerdasan visual spasial dan kecerdasan logis matematis terhadap prestasi belajar geometri. Jurnal Pemikiran dan Penelitian Pendidikan Matematika, 1 (2), 105-123.

Nurrita, T. (2018). Pengembangan media pembelajaran untuk meningkatkan hasil belajar siswa. Jurnal MiSYKAT, 3 (1), 171-187.

Pandin, R., Maonde F., \& Sudia, M. (2019). Pengaruh kombinasi model pembelajaran kooperatif dan motivasi berprestasi terhadap hasil belajar matematika siswa smp. Jurnal Pendidikan Matematika, 9 (2), 185193.

https://dx.doi.org/10.36709/jpm.v9i2. 5868

Purnomo, Y. (2017). Pengaruh sikap siswa pada pelajaran matematika dan kemandirian belajar siswa terhadap prestasi belajar matematika. Jurnal Kajian Pendidikan Matematika, 2 (1), 93-105.

http://dx.doi.org/10.30998/jkpm.v2i1 .1897

Purwati, \& Nurhasanah. (2016). Deskripsi pengaruh kecerdasan emosional terhadap prestasi belajar mahasiswa pendidikan matematika unipa. Pancaran, 5 (4), 169-178.

Putri, W. (2018). Pendidikan berbasis multiple intelligences. Al-Ikhtibar: Jurnal Ilmu Pendidikan, 5 (2), 671686.

https://doi.org/10.32505/ikhtibar.v5i2 .555
Ratumanan, T. G., \& Laurens, T. (2016). Analisis penguasaan objek matematika. Jurnal Pendidikan Matematika Raflesia, 1 (2), 146-154. https://doi.org/10.31186/jpmr.v1i2.40 05

Said, A. \& Budimanjaya, A. (2015). Strategi mengajar multiple intelegences. Jakarta: Prenadamedia Group.

Sastro, G. (2018). Pengaruh kebiasaan belajar siswa dan kecerdasan emosi serta perhatian orang tua terhadap penguasaan konsep matematika. Jurnal Saintika Unpam : Jurnal Sains dan Matematika Unpam, 1 (1), 133157.

http://dx.doi.org/10.32493/jsmu.v1i1. 1608

Setiawan, A. R., \& Ilmiyah, S. (2020). Kecerdasan majemuk berdasarkan neurosains. Diakses tanggal 5 Desember $2020 \quad$ dari https://www.researchgate.net/publica tion/340598728_Kecerdasan_Majem uk_Berdasarkan_Neurosains

Sholihatunnisa, L., Darmawansyah, M. I., Sa'adah, N., \& Susilawati, W. (2018). Problematika pendidik dan peserta didik terhadap pelajaran matematika. Jurnal Prisma, 7 (2), 145-163. https://doi.org/10.35194/jp.v7i2.249

Siagian, M. D. (2016). Kemampuan koneksi matematik dalam pembelajaran matematika. Journal of Matematics Education and Science, 2 (1), 58-67. https://doi.org/10.30743/mes.v2i1.11 7

Situmorang, R. U., \& Sopia, N. (2020). Meningkatkan hasil belajar siswa melalui penggunaan alat peraga pada 
materi geometri ruang. J-PiMat: Jurnal Pendidikan Matematika, 2 (1), 168-174. https://doi.org/10.31932/jpimat.v2i1.686

Slameto. (2013). Belajar dan faktor-faktor yang mempengaruhi. Jakarta: Rineka Cipta.

Sudaryono. (2012). Dasar-dasar evaluasi pembelajaran. Yogyakarta: Graha Ilmu.

Sudjana, N. (2010). Penilaian hasil proses belajar mengajar. Bandung: PT. Remaja Rosdakarya.

Sugiyati. (2016). Pengaruh media pembelajaran dan minat belajar terhadap hasil belajar matematika. Jurnal Penelitian dan Penilaian Pendidikan, 1 (2), 227-241.

Sukardjo, M., \& Yusdiningtias, K. (2018). Pengaruh strategi pembelajaran dan kecerdasan logis matematis terhadap hasil belajar matematika sekolah dasar kelas vi. Jurnal Pendidikan Edutama, 5 (1), 101-113. http://dx.doi.org/10.30734/jpe.v5i1.1 36

Syafiqah, A., Ruslan., \& Darwis. (2020). Deskripsi kecerdasan visual spasial siswa dalam memecahkan masalah bangun ruang sisi datar ditinjau berdasarkan tingkat kemampuan awal geometri pada siswa kelas vii smp. Issues in Mathematics Education, 4 (1), 68-82.

Utami, Y. P., Alan, D., \& Cahyono, D (2020). Studi at home: analisis kesulitan belajar matematika pada proses pembelajaran daring. Jurnal Ilmiah Matematika Realistik (JI-MR), 1 (1), 20-26.
Wulandari, L., \& Fatmahanik, U. (2020). Kemampuan berpikir logis matematis materi pecahan pada siswa berkemampuan awal tinggi. Laplace: Jurnal Pendidikan Matematika, 3 (1), 43-57.

https://doi.org/10.31537/laplace.v3i1. 312

Zahra, C., Widyawati, S., \& Ningsih, E. F. (2017). Eksperimentasi model pembelajaran kooperatif tipe student facilitator and explaining (sfe) berbantuam alat peraga kotak imajinasi ditinjau dari kecerdasan spasial. JIPMat, 2 (2), 97-104. https://doi.org/10.26877/jipmat.v2i2. 1972 